\title{
BLAST FURNACE GRANULAR COAL INJECTION SYSTEM
}

Final Report Volume 2

Project Performance and Economics

Work Performed Under Cooperative Agreement No.: DE-FC21-91MC27362

For

U.S. Department of Energy

Office of Fossil Energy

Federal Energy Technology Center

P. O. Box 880

Morgantown, West Virginia 26507-0880

By

Bethlehem Steel Corporation

Bethlehem, Pennsylvania 18016

October 1999 


\section{DISCLAIMER}

This report was prepared by Bethlehem Steel Corporation pursuant to a cooperative agreement funded partially by the U. S. Department of Enercy, and neither Bethlehem Steel nor any of its subcontractors nor the U. S. Department of Energy, nor any person acting on behalf of either:

(a) Makes any warranty or representation, express or implied with respect to the accuracy, completeness, or usefulness of the information contained in this report, or that the use of any information, apparatus, method, or process disclosed in this report may not infringe privately owned rights; or

(b ) Assumes any liabilities with respect to the use of, or for damages resulting from the use of any information, apparatus, method or process disclosed in this report.

Reference herein to any specific commercial product, process, or service by trade name, Trademark, manufacturer, or otherwise does not necessarily constitute or imply its endorsement, recommendation, or favoring by the U. S. Department of Energy. The views and opinions of authors expressed herein do not necessarily state or reflect those of the U. S. Department of Energy. 


\begin{abstract}
Bethlehem Steel Corporation (BSC) requested financial assistance from the Department of Energy (DOE), for the design, construction and operation of a 2,800-ton-per-day blast furnace granulated coal injection (BFGCI) system for two existing iron-making blast furnaces. The blast furnaces are located at BSC's facilities in Burns Harbor, Indiana. The demonstration project proposal was selected by the DOE and awarded to Rcthlehem in November 1990. The design of the project was completed in December 1993 and construction was completed in January 1995 . The equipment startup period continued to November 1995 at which time the operating and testing program began. The blast furnace test program with different injected coals was completed in.December 1998.

This Final Report is designated as Volume 2. Volume 1, as specified in the general guidelines for project reporting, is the Public Design Report of March 1995 that is referenced in the Bibliography, Section 10 of this report.

BFGCI technology involves injecting coal directly into an ironmaking blast furnace and thereby reduces the need for coke on approximately a pound of coke for a pound of coal basis. This demonstration project is a full-scale application of the commercial version of the BFGCI system that is available to the integrated steel industry. The Burns Harbor BFGCI system demonstrated that:
\end{abstract}

- A coal preparation system can be used to inject granular coal as well as pulverized coal. No other system has been utilized over this range of coal sizes.

- The costs for granular coal systems can be less than for pulverized systems.

The primary goal of the BFGCI and the Cooperative Agreement with the Department of Energy was to demonstrate the advantages of using a granular coal injection facility rather than a pulverized coal injection system. Secondary objectives were to determine the effect of coal grind size and coal type on blast furnace performance.

The major conclusion based on three years of operational experience with the granulated coal injection system is that granular coal works very well in a large blast furnace.

Specific conclusions from the blast furnace trials are:

1) Granular coal performs as well as pulverized coal in large blast furnaces.

2) The energy consumption for granulating coal is significantly less than that required for pulverizing coal. Specifically, $60 \%$ less energy is consumed in coal grinding when producing granular sized coal, a significant economic benefit.

3) The blast furnace operation with low volatile coal is superior to an operation using high volatile coal. 


\section{POINTS OF CONTACT}

1. T. J. Strayer Bethlehem Steel Corporation Homer Research Laboratories Bldg. C Bethlehem, Pa. 18015 (610) 694-3749

2. D. G. Hill Bethlehem Steel Corporation Burns Harbor Plant

Blast Furnace Department Burns Harbor, Indiana 46304

(219) $787-2456$ 
TABLE OF CONTENTS

\section{Page}

1.0 INTRODUCTION $\quad \cdots \quad 1$

1.1 Overview of the Project 1

1:1.1 Background and History of the Project 1

1.1.2 Project Organization - Phase I and II 2

1.1.3 Project Organization - Phase III $\quad 3$

1.1.4 Project Description 3

1.2 Demonstration Project Goals $\quad 4$

1.2.1 Coal Particle Size 4

1.2.2 Coal Chemistry and Type 5

1.2.3 Coal Injection versus Natural Gas . 5

2.0 TECHNOLOGY DESCRIPTION 6

2.1 Description of the Demonstrated Technology 6

2.2 Description of the Demonstration Facilities 6

2.2.1 Raw Coal Supply $\quad 6$

2.2.2 Raw Coal Reclaim $\quad 6$

$\begin{array}{lll}\text { 2.2.3 Coal Preparation } & 7\end{array}$

$\begin{array}{ll}\text { 2.2.4 Coal Injection } & 7\end{array}$

2.2.5 Process Building 7

2.2.6 Utilities Building 8

2.2.7 Environmental Control Facilities 8 


\section{Page}

$\begin{array}{lc}2.3 \text { Process Flow Diagram } & 8\end{array}$

3.0 UPDATE OF THE PUBLIC DESIGN REPORT 9

4.0 DEMONSTRATION PROGRAM , 9

4.1 Test Plans 99

4.1.1 Blast Furnace Trials 9

4.2 Operating Procedures $\quad 9$

4.2.1 BFGCI Instrumentation and Data Acquisition $\quad 10$

4.2.2 Blast Furnace Level II Process Control $\quad 10$

4.2.3 Critical Component Failure Analysis $\quad 10$

5.0 TECHNICAL PERFORMANCE 11

5.1 Blast Furnace Granular Coal Injection - Results With Low Volatile Coal

5.1.1 Background $\quad \cdot \quad 11$

5.1.2 Blast Furnace Operations $\quad 11$

5.1.3 Furnace Operating Conditions 12

5.1.4 Furnace Thermal Conditions and Lining Wear $\quad 14$

5.1.5 Discussion 1.4

5.2 Blast Furnace Granular Coal Injection - Results With Higher Ash Coal

5.2.1 Blast Furnace Operations $\quad 15$

5.2.2 Trial Coal Selection $\quad 15$

5.2.3 C Furnace Operations 16

5.2.4 General Trial Observations $\quad 16$

5.2.5 Furnace Coke Rate Results 16 
5.3 Blast Furnace Granular Coal Injection Results Using Pulverized and Granulated High Volatile Coal

5.3.1 The D Furnace Operation

5.3.2 General Trial Observations

5.3.3 Coal Chemistry and Sizing

5.3.4 Furnace Coke Rate Results

5.3.5 Coal Grinding Energy Consumption

5.3.6 Conclusions

6.0 ENVIRONMENTAL PERFORMANCE 23

6.1 Monitoring of the BFGCI Facility 23

6.2 Environmental Monitoring for the Trial Periods 23

6.3 Wastewater Monitoring Results $\quad 23$

6.4 Gaseous Stream Testing Results $\quad 24$

$\begin{array}{lll}7.0 & \text { ECONOMICS } & 25\end{array}$

7.1 Project Capital Costs 25

7.2 Operating and Maintenance Costs 25

7.3 Burns Harbor Plant Economic Analysis 26

7.4 Generalized Economic Analysis $\quad 27$

8.0 COMMERCIALIZATION POTENTIAL 28

8.1 Market Analysis and Size 29-

9.0 CONCLUSIONS $30^{\circ}$

$\begin{array}{lll}10.0 & \text { BIBLIOGRAPHY } & 31\end{array}$ 


\section{LIST OF TABLES}

Number

Title

Page

Table 1

Facility Design Parameters

32

Table 2

Blast Furnace Coal Injection Reference Reports

33

Table 3

Blast Furnace Granulated Coal Injection

Environmental Reports

Table 4

Blast Furnace Granulated Coal Injection Trial Reports

Table 5

Base Period Evaluation Burns Harbor C Furnace

Summary of Operations

Table 6

Burns Harbor C Furnace Coal Analysis and Sizing

Table 7

Burns Harbor C Furnace Sulfur Balance

38

Table 8

Injection Coal Analysis - Burns Harbor

High Ash Coal Trial

Table 9

Burns Harbor C Furnace - Summary of Operations

During the High Ash Coal Trial

Table 10

Burns Harbor C Furnace - Adjusted Coke

Rate Comparison for the High Ash Coal Trial Using

May 1997 as a Base Period

Table 11

Burns Harbor C Furnace - Adjusted Coke

Rate Comparison for the High Ash Coal Trial Using

October 1996 as a Base Period

Table 12

Burns Harbor C Furnace Sulfur Balance

High Ash Coal Trial

Table 13

D Furnace - Trials with High Volatile Coal

Table 14

Coal Chemistry Comparison of Low Volatile and High Volatile Coal 


\section{LIST OF TABLES (continued)}

Number

Title

Page

Table 16

Burns Harbor D Furnace Adjusted Coke Rate

Comparison - Granular Low Volatile Coal

Compared to Granular High Volatile Coal

Table 17

Burns Harbor D Furnace Adjusted Coke Rate

Comparison - Granular High Volatile Coal

Compared to Pulverized High Volatile Coal

Table 18

Burns Harbor D Furnace Sulfur Balance

Granular High Volatile Coal Trial

Table 19

Burns Harbor Division Closed Water System Analysis

50

Table 20

Gaseous Stream Testing

Table 21

Granular Coal Injection Project

Estimated Cost Summary

Table 22

Burns Harbor Coal Preparation \& Injection

Equipment List for One Blast Furnace

Table 23

Burns Harbor Coal Injection Operating and

Maintenance Costs

Table 24

USA Blast Furnace and Injection Material List 


\section{LIST OF FIGURES}

Number

Title

$\underline{\text { Page }}$

Figure 1

Phase I and Phase II Project Organization

Figure 2

Phase III Project Organization

Figure 3

Project Milestone Dates

58

Figure 4

Coal Injection - Burns Harbor Plant

59

Figure 5

Application of Coal Injection

60

Figure 6

Burns Harbor C Furnace - Permeability and Injected Coal Rate

Figure 7

Burns Harbor C \& D Furnaces Regression Analysis Injected Coal vs Adjusted Coke Rate

Figure 8

Burns Harbor - Coal Grinding Mill

Energy Consumption

Figure 9

Burns Harbor Division Closed Water System

64

Figure 10

Effect of Changes in Natural Gas and Coal Injection

Costs on Cost Savings at Burns Harbor with Purchased

Coke Costing \$130/Ton

Figure 11

Effect of Changes in Natural Gas and Coal Injection

Costs on Cost Savings at Burns Harbor with Purchased

Coke Costing $\$ 100 /$ Ton 


\section{LIST OF ABBREVIATIONS}

$\begin{array}{ll}\mathrm{Al}_{2} \mathrm{O}_{3} & \text { Aluminum Oxide } \\ \mathrm{BFGCI} & \text { Blast Furnace Granular Coal Injection } \\ \mathrm{BSC} & \text { Bethlehem Steel Corporation } \\ \mathrm{C} & \text { Carbon } \\ \mathrm{CaO} & \text { Calcium Oxide } \\ \mathrm{CCT} & \text { Clean Coal Technology } \\ \mathrm{Cl} & \text { Chlorine } \\ \mathrm{DOE} & \text { U. S. Department of Energy } \\ \mathrm{H} \text { or } \mathrm{H}_{2} & \text { Hydrogen } \\ \mathrm{K}_{2} \mathrm{O} & \text { Potassium Oxide } \\ \mathrm{M} & \text { Mesh } \\ \mathrm{MgO} & \text { Magnesium Oxide } \\ \mathrm{MMI} & \text { Man Machine Interface } \\ \mathrm{N} \text { or } \mathrm{N}_{2} & \text { Nitrogen } \\ \mathrm{Na} & \text { Podium Oxide } \\ \mathrm{O} \text { or } \mathrm{O}_{2} & \text { Primary Logic Control } \\ \mathrm{P}_{2} \mathrm{O}_{5} & \text { Oxygen } \\ \mathrm{PLC} & \end{array}$




\section{LIST OF UNITS}

Btu

$\mathrm{Btu} / \mathrm{hr} / \mathrm{ft}^{2}$

Grs.

HGI

$\mathrm{kWh}$

$\mathrm{mg} / \mathrm{l}$

NTHM

scf

MMBtu

TPH
British Thermal Unit

British Thermal Unit per hour per square foot

Grains

Hargrove Grindability Index

Kilowatt hour

Milligrams per liter

Net tons of hot metal

Standard cubic feet

One million British Thermal Units

Tons per hour 


\section{GLOSSARY OF TERMS}

Bosh - an area above the tuyeres

Burden - the solid mixture of iron ore, coke, and limestone that descends through the furnace

Coke replacement ratio - pounds of coke replaced per pound of coal injected

Granular Coal - powdered coal with10-30\% passing through a 200-mesh screen

Hearth - bottom of furnace, where liquid metal and slag collect

Hot blast - heated air produced in the stoves and injected into the furnace

Permeability - a measure of the ability of the combustion gas to pass through the furnace burden

Productivity - net tons of hot metal produced(NTHM) per unit time, usually a day

Pulverized coal - powdered coal with 70-80\% passing through a 200-mesh screen

Raceway - a channel around the bottom of the furnace created by the injected hot blast

Reducing gas - gas produced by the partial combustion of carbon in the furnace, primarily carbon monoxide

Slag - solid residue remaining after the reduction of iron ore to iron; primarily calcium and aluminum oxides plus other elements such as magnesium, sodium, potassium, etc.

Slag volume - a measure of the amount of slag produced, usually expressed in pounds per NTHM

Stack - truncated upright cone portion of the blast furnace

Taphole - openings below the tuyeres through which the molten iron and slag are removed from the furnace

Tuyeres - openings through which the hot blast is injected into the furnace 


\section{EXECUTIVE SUMMARY}

Bethlehem Steel Corporation (BSC), of Bethlehem, Pennsylvania requested financial assistance from the Department of Energy (DOE), for the design, construction and operation of a 2,800-ton-per-day blast furnace granulated coal injection (BFGCI) system for two existing iron-making blast furnaces. The blast furnaces retrofitted with BFGC: each have the capacity of 7,000 net ton of hot metal (NTHM) per day. The blast furnaces are located at BSC's facilities in Burns Harbor, Indiana. The demonstration project proposal was selected by the DOE and awarded to Bethlehem in November 1990. The design of the project was completed in December 1993 and construction was completed in January 1995. The equipment startup period continued to November 1995 at which time the operating and testing program began. The blast furnace test program with different coals was completed in December 1998. The total project cost was $\$ 190,650,000$, with DOE's share being $\$ 31,260,000$ or $16.4 \%$ of the total.

The principal purpose of a blast furnace is to smelt iron ores to produce pig iron that is the primary ingredient in the production of steel. Other raw materials consumed in the smelting process are coke, which is the primary fuel and reducing agent; limestone and dolomite, which act to flux the earthy constituents in the iron-bearing materials and coke ash to form a slag; and hot air and oxygen, which are needed to support combustion of the coke. Supplemental fueis such as fuel oil and natural gas have been used at the Burns Harbor facility to replace some of the coke. The blast furnace produces a slag which is skimmed from the molten pig iron. The slag contains most of the impurities from the raw materials. The slag can be utilized as an aggregate material in the manufacture of roadfill or cement. Thus, the sulfur introduced by the direct injection of coal becomes a constituent in a useful by-product.

BFGCI technology involves injecting coal directly into an ironmaking blast furnace and thereby reduces the need for coke on approximately a pound of coke for a pound of coal basis. Coke was replaced with direct coal injection up to about 280 pounds per NTHM. The reducing environment of the blast furnace enables the capture of almost all the sulfur by the slag and hot metal. The gases exiting the blast furnace are cleaned by cyclones and wet scrubbers to remove particulates. The cleaned blast furnace gas is thên used as a fuel in other steel plant processes.

BSC is the signatory of the Cooperative Agreement, the owner and operator of the demonstration facility and provided the site and blast furnaces to conduct the project. In addition, the project team included ATSI, Inc. of Buffalo, New York; Simon Macawber, Ltd., Doncaster, England; and British Steel Consultants Overseas Services, Inc., a marketing arm of British Steel. The BFGCI equipment was developed by British Steel and Simon Macawber. Simon Macawber is currently known as Clyde Pneumatic. 
This demonstration project was a full-scale application of the of the BFGCI system that is available to the integrated steel industry. The Burns Harbor BFGCI system demonstrated that:

- A coal preparation system can be used to inject granular coal as well as pulverized coal. No other system has been utilized over this range of coal sizes.

- The costs for granular coal systems can be less than for pulverized systems.

- Granular coal is easier to handle in pneumatic conveying systems. Granular coals are not as likely to stick to conveying pipes if moisture control is not adequately maintained.

- The unique variable speed, positive displacement Simon-Macawber injectors provide superior flow control and measurement compared to other coal injection systems.

The main facilities that were installed and demonstrated included a coal storage area, a coal reclaim facility, a drying and grinding facility, and a furnace injection system. The drying and grinding facility was designed to produce coals ranging in size consist from $80 \%-200$ mesh(pulverized coal) to $30 \%-200$ mesh(granular coal).

In addition to displacing the natural gas, the injected fuel previously used at Burns Harbor, the coal injected through the tuyeres displaced coke, which is the primary reductant and fuel in the blast furnace. The Burns Harbor project generated operating data and trial results that are applicable to the domestic integrated steel industry.

The primary goal of the Project and the Cooperative Agreement with the Department of Energy was to demonstrate the advantages of using a granular coal injection facility compared to a pulverized coal injection system. Secondary objectives were to determine the effect of coal grind size and coal type on blast furnace performance.

The major conclusion based on three years of operational experience with the granulated coal injection system is that granular coal works very well in a large blast furnace.

Specific conclusions from the four blast furnace trials, discussed in detail in the Technical Performance section of this report, are as follows:

1) Granular coal performs as well as pulverized coal in large blast furnaces.

2) The energy consumption for granulating coal is significantly less than that required for pulverizing coal. Specifically, $60 \%$ less energy is consumed in coal grinding when producing granular sized coal. This is a substantial economic benefit.

3) The blast furnace operation with low volatile coal is superior to the operation using high volatile coal. 
4) Granular coal sizing is a key attribute for the successful use of low volatile injection coal.

5) Low volatile coal replaces more coke in the blast furnace than an equal amount of high volatile coal.

6) Higher ash content in the injected coal results in increased furnace coke rates. There is a coke rate disadvantage of three pounds/NTHM for each one per cent increase of ash at an injection rate of 260 pounds/NTHM. However, the higher ash coal had no adverse effect on furnace permeability or productivity. 


\subsection{INTRODUCTION}

This final report describes the Blast Furnace Granular Coal Injection project that was implemented at the Burns Harbor Plant of Bethlehem Steel Corporation. This demonstration project was part of Round III of the DOE Clean Coal Technology (CCT) Program. The project received cost sharing from the U.S. Department of Energy (DOE), and is administrated by the Federal Energy Technology Center in accordance with the DOE Cooperative Agreement No. DE-FC21-91MC27362.

This installation is the first in the United States to use British Steel technology that provides granular coal as a portion of the fuel requirements of a blast furnace. The project demonstrated and assessed a broad range of technical and economic issues associated with the use of coal for injection into blast furnaces. To achieve the program objectives, the demonstration project was divided into the following three Phases:

\section{Phase I - Design \\ Phase II - Construction \\ Phase III - Operation}

Preliminary Design (Phase I) began in 1991 with detailed design commencing in 1993. Construction at the Burns Harbor Plant (Phase II) began in August 1993 and was completed at the end of 1994. The demonstration test program (Phase III) started in the fourth quarter of 1995 and was completed in December 1998.

\subsection{Overview of the Project}

\subsubsection{Background and History of the Project}

It was recognized over a hundred years ago that injecting hydrocarbons through blast furnace tuyeres would decrease coke requirements. Hydrocarbon injection does alter the heat balance in the lower section of the furnace. The combustion of fuels, such as oil, natural gas or coal that are injected through the tuyere, produce reducing gases with a lower temperature than what is achieved by burning coke that has been preheated inside the blast furnace to over 2000 degrees F. Additionally, when the injected fuel has a high hydrogen to carbon atomic ratio, less heat is generated in the combustion of that fuel to $\mathrm{CO}$ and $\mathrm{H}_{2}$. Natural gas has a hydrogen to carbon ratio of 4 to 1 ; the comparative values for fuel oil and bituminous coal are 1.5 to 1 and 0.75 to 1 , respectively.

The selection of coal in preference to other injectants is based on the fact that the endothermic effect of coal on the high temperature heat supply to the lower part of the furnace is the smallest of all injected fuels. Coal injection into blast furnaces was the earliest form of tuyere injection with experiments beginning in France between 1840 and 1845. Paddles or primitive screw feeders were used to introduce coal into the air blast close to the tuyeres. The practice continued for several years. Besides some unsuccessful attempts at pneumatic injection of coal between 1910 and 1920 and 
experiments in the USSR in the early 1950's, it was not until 1959 and the early 1960 's that coal injection was successfully practiced. Trials at Buffalo in the USA, Louvroil in France and Stanton in England proved that the technology was available for pneumatic injection of coal, but the economics were such that oil and natural gas became the most popular tuyere injectant fuel world-wide. The exceptions were at Armco Steel, now AK Steel, in the USA and Shoudu Iron and Steel Company in China, where coal injection has been practiced from the mid-1960's until the present day.

The 1960 trials in the United Kingdom proved that the technology existed for pneumatic injection of granular coal. The trials used coal with a size consist of $100 \%$ less than $1 / 8$ inch $(3.2 \mathrm{~mm})$ and approximately $11 \%$ less than 74 micron. This size coal is easier and less expensive to produce, using a hammer mill, than is finer, pulverized coal with equipment such as a ball or roller mill pulverizers. The trials also showed that granular coal would flow well using pneumatic conveying techniques. Injection rates of up to 360 pounds per net ton of hot metal (NTHM) were achieved using a variety of coals. The coal was found to reduce the need for coke on an equivalent weight basis. Coal injection was discontinued, however, because of lower oil prices.

The facility installed by Bethlehem Steel Corporation (BSC) uses Blast Furnace Granulated Coal Injection (BFGCI) technology developed jointly by British Steel and Simon Macawber. The BFGCI technology was first used on British Steel's Queen Mary blast furnace at the Scunthorpe Works. Based on the Queen Mary performance, coal injection was installed on Scunthorpe's Queen Victoria, Queen Anne and Queen Bess (operational standby) blast furnaces and on Blast Furnaces 1 and 2 at the Ravenscraig Works. Queen Victoria's system was brought on line in November 1984 and Queen Anne's in January 1985. The Ravenscraig systems were started up in 1988.

Although British Steel discontinued the operation of its Ravenscraig blast furnaces in early 1993 in response to a contraction of the steel market, BFGCI is still employed on Scunthorpe's four blast furnaces.

\subsubsection{Project Organization - Phase I and II}

BSC is the owner and operator of the facility and the program manager as defined under the Cooperative Agreement with the DOE. As the program manager, BSC placed a turnkey contract with Fluor Daniel, Inc., Greenville, SC, for engineering, procurement, construction, training, commissioning, and performance testing of the raw coal handling, coal preparation and coal injection systems. Fluor Daniel placed a subcontract with ATSI/Simon Macawber, Amherst, NY, for the design and supply of equipment associated with the injection system. Figure 1 shows a schematic organization chart for these two phases of the project.

The injection facility provides for the storage and handling of dry, granular coal-after it leaves the coal preparation facility until it is injected into the blast furnace. The injection facility technology involving the handling and control of the granular coal through the injection facility is provided by a joint venture company, ATSI - Simon Macawber 
(ATSI/SM), in Amherst, NY. ATSI/SM has the license to market the technology in North America. ATSI/SM obtained the license from Simon Macawber, United Kingdom, who has the license to market the technology worldwide. The injection technology includes the design of the injection facility components and supply of the proprietary hardware from Simon Macawber, Doncaster, United Kingdom. ATSI/SM also furnished training and startup services as part of their supply. Simon Macawber is now known as Clyde Pneumatic.

BSC contracted with British Steel, PLC, for the supply of blast furnace operation knowhow and startup technical assistance. This included operational, maintenance and safety instruction manuals, pre-startup training for BSC personnel at British Steel's Scunthorpe Works, facility start up services at the Burns Harbor Plant, and consulting services for a two year period after commissioning.

\subsubsection{Project Organization - Phase III}

The organization for the testing and demonstration phase of the project is shown in Figure 2. At this point in the project, the responsibility for the test work and results of the project became the obligation of BSC. In particular, the operating personnel at the Burns Harbor blast furnace, with support of many other disciplines, administered the test and results portion of the project.

\subsubsection{Project Description}

The ironmaking blast furnace is at the heart of the integrated steelmaking operations. This is where iron ore, limestone and coke are charged into a countercurrent shaft reactor. These raw materials are put into the furnace at the top and descend to form a molten pool of iron at the bottom of the furnace. Preheated air or hot blast enters the furnace through a series of ports (tuyeres) around and near the base of the furnace. Reduction of the descending ore occurs by the reaction with the rising hot reducing gases that is produced when coke is burned at the tuyeres. The molten iron is transported to the steelmaking area, purified and alloyed to steel to begin the process that results in recognizable products such as automobiles, home appliances, bridges and skyscrapers.

Bethlehem Steel Corporation operates two blast furnaces, C and D, as part of an integrated flat-rolled facility at Burns Harbor, Indiana. The two furnaces are very similar in size and construction. These furnaces have normally been operated at production rates of 6600-7100 NTHM/day. Although both furnaces have low coke consumption rates, the coke required for this production level exceeds the capacity of the two coke oven batteries at the plant. With the cost of supplementing the home coke supply projected to rise along with concerns about the availability and quality, Bethlehem sought to improve the blast furnace operation while decreasing the consumption of coke. 
To reduce coke consumption, many fuels have been injected to the blast furnace through the tuyeres. Tar, oil and natural gas have all been used at Burns Harbor to reduce the coke requirement. The local economics of coke and the cost and availability of each injectant has been the driving force for which fuel to use at any particular point in time. Prior to 1995, Burns Harbor used natural gas as an injectant. Despite the simplicity of operation, lack of large capital outlay and the good results from natural gas, blast furnace operators realized the limitations of gas, the inevitable increase in price and a concern on future availability.

Prior to the construction of the Granulated Coal Injection System at Burns Harbor, all coal injection facilities in the United States were designed to provide pulverized coal. Pulverized coal is defined as $70 \%-80 \%$ of the injected product coal being -200 mesh. Granulated coal is defined as the final ground coal size injected to the furnace as being:

$$
\begin{aligned}
& 100 \% \text { is }-4 \text { mesh }(5 \mathrm{~mm}) \\
& 98 \% \text { is }-7 \text { mesh }(3 \mathrm{~mm}) \\
& <30 \% \text { is }-200 \text { mesh }
\end{aligned}
$$

A major advantage of granulated versus pulverized coal is that less energy is required for grinding. The granulated coal injection system is also easier to maintain. In addition, the Burns Harbor system has the ability to produce either pulverized or granulated coal, albeit at a reduced production level when preparing pulverized coal. The flexibility of the equipment was important for the coal testing program.

The Burns Harbor project has been conducted to generate data that is applicable to the entire domestic integrated steel industry. The project has demonstrated sustained operation with a variety of coal types, sizes and chemistry. The operation with the injected coal has been compared to the blast furnace operation with natural gas, the previous tuyere injectant used at Burns Harbor. In addition, trials were completed comparing the use of the same coal with granular and pulverized sizing.

\subsubsection{Project Schedule}

The project schedule is shown in Figure 3. A much more comprehensive and detailed project management time line schedule showing engineering, procurement and construction activities is available in the Public Design Report dated March 1995.

\subsection{Demonstration Project Goals}

The goals that were completed as part of the project are described in the following sections. 


\subsubsection{Coal Particle Size}

Operation of the BFGCI system was demonstrated for primarily granular sized coal. The initial six month operation of the furnace with high volatile coal on $\mathrm{C}$ furnace showed the operating characteristics of the blast furnace with granular coal. The trial schedule was designed to show the advantages of granular coal which are reduced capital costs for grinding facilities and reduced energy consumption for the grinding process. The direct comparison of granular and pulverized coal sizing was completed in October and November 1998.

\subsubsection{Coal Chemistry and Type}

The effect of coal chemistry, in particular, higher ash content, on blast furnace performance was demonstrated and categorized. In addition, two coal types, high and low volatile with granular sizing were directly compared.

\subsubsection{Coal versus Natural Gas}

The blast furnace process advantages of the use of granular coal compared to the historical use of natural gas at Burns Harbor were also evaluated. This comparison is discussed in section 5.1.3 and illustrated in Table 5. 


\subsection{TECHNOLOGY DESCRIPTION}

The injection of coal into the blast furnaces at Burns Harbor required the installation of major new facilities and modifications to some existing facilities. The scope of this work is categorized into the following areas - raw coal supply, raw coal reclamation, coal preparation, coal injection, peripheral facilities and environmental control facilities. The following description of the technology and the facilities is a summary of previous reports. A detailed description of the facilities with appropriate engineering drawings is available in the Public Design Report of March 1995. The facilities are shown schematically in Figure 4.

\subsection{Description of the Demonstrated Technology}

The BFGCI technology was developed to use bituminous coals that are typically used by the power generation industry. The preparation of the coal (grinding and drying) can be done by a variety of commercially supplied mill systems that are also used by the power generation industry. In fact, a very simple, low cost hammer mill would be sufficient to produce the granular coal specification developed by British Steel. However, the need to demonstrate both granular and pulverized coal sizes precluded a hammer mill from being used for this facility.

A schematic of the Burns Harbor system is shown in Figure 5. The granular coal injection technology (storing, metering and transporting the granular coal into the furnace) was supplied by ATSI/SM. The granular technology includes the design of the injection system, the product coal silos, weigh bins, distribution bins, injectors, injection lines, injection lances and control system. The technology also includes the supply of injectors, injection piping system components, and injection lances by Simon Macawber.

\subsection{Description of the Demonstration Facilities}

Each component of the coal injection system is reviewed in the following sections of this report.

\subsection{1 $\quad$ Raw Coal Supply}

Raw coal is shipped from the coal mine to the Burns Harbor Plant by rail in unit trains of 100 cars. The coal is unloaded with an existing car dumper. As part of the coal injection project, one existing conveyor was elevated to provide room for a diverter gate to reroute coal to the coal injection facility. A new 60 inch wide conveyor was built to supply coal to a 28,000 ton coal pile area to maintain a $10-14$ day supply of coal.

\subsubsection{Raw Coal Reclaim}

A raw coal reclaim tunnel was built under the coal storage pile. The reclaim hoppers in the tunnel feed a 36 inch wide reclaim conveyor. The $\mathbf{4 0 0}$ foot long conveyor transports 
the coal at a rate of 400 tons per hour above ground to the south of the storage pile. The coal is sent to a precrusher and then to the top of the coal preparation process building.

\subsubsection{Coal Preparation}

Coal is transferred from the reclaim conveyor to a distribution conveyor that directs the coal into one of two raw coal storage bins. Each bin holds 240 tons of coal. They are totally enclosed with a vent filter on top.

From the bins, coal flows into a feeder that controls the flow to the Williams coalgrinding mill. The mill is driven by a 500HP variable speed motor. The mill contains six roller journals that rotate about a vertical axis against the inside diameter of the 90 inch bowl ring. The faster the journal rotates the greater the crushing force against the bowl ring. The coal particle size is largely controlled by the mill rotational speed. Heated air from a natural gas fired burner is mixed with recycled air and sweeps the coal through the mill-grinding chamber.

The coal and gas mixture pass through a cyclone separator where $95 \%$ of the coal fines are separated from the gas. There are two Williams Patent Crusher grinding/drying mill systems. Each system is designed to produce 30 tons per hour of pulverized coal or 60 tons per hour of granular coal.

\subsubsection{Coal Injection}

The coal injection facility consists of four parallel in-line series of equipment, two for each furnace. Each series of equipment begins with the screw feeder to the product coal silo and ends with the coal injection lance at the blast furnace tuyere.

Coal from the two product coal screens is directed to four screw feeders that feed four product coal silos. Each silo holds 180 tons of coal. This is sufficient to maintain coal injection at 60 tons per hour for six hours. This system is designed as an oxygen exclusion system. Coal flows by gravity to an enclosed distribution bin that serves as a holding area for the individual two ton batches. The distribution bin contains 14 conical shaped pant legs each of which feeds an injector. The injector contains a lockhopper with a screw feeder at the bottom. The screw feeder meters the coal from the injector vessel to the injection line. At this point the coal is mixed with high pressure air and is carried approximately 600 feet to an injection lance mounted on each of the 28 blow pipes on the blast furnaces.

\subsubsection{Process Building}

The coal preparation system and injection plant system equipment is in a process building located to the west of the blast furnaces. The building has a plot cross-section of. 56 feet $\times 76$ feet and has two roof levels at 45 and 105 feet above grade. 


\subsubsection{Utilities Building}

The utilities building houses all motor controls, electrical switchgear, injection air compressors, HVAC, spare parts and the main control room.

\subsubsection{Environmental Control Facilities}

The facility complies with all of the State of Indiana environmental regulations. Also, a project Environmental Assessment was approved by the DOE in May 1993. The Public Design Report of March 1995 provides a complete description of the method and facilities that provide environmental compliance.

\subsection{Process Flow Diagram}

Figure 4, referred to previously, shows a general layout of the flow of coal from the unloading point to the blast furnace. Figure 5 shows the application of the granulated coal injection system and its relative place in the larger scheme of the entire blast furnace complex. In addition, Table 1 shows the Facility Design Parameters for the entire system. The capacity of each of the elements in the simplified process flow diagram is noted in this table. Additional detailed stream data of each element in the system with appropriate mass flow rates are available in the Public Design Report in drawings numbered 200/300-59J-01 and 100-250-00. 


\subsection{UPDATE OF THE PUBLIC DESIGN REPORT}

There were no substantive changes made to the BFGCI equipment or to any of the other material reported on and issued in the Public Design Report of March 1995.

\subsection{DEMONSTRATION PROGRAM}

The demonstration phase of the BFGCI system consisted of two process evaluations: the operation of the coal grinding and delivery system to the blast furnace and the effect of coal injection on the blast furnace. The startup and initial operation of the BFGCI system was assessed during the first five months of operation as blast furnace operating practices with the new equipment were developed. For the blast furnace process evaluation, four trials were conducted during the three-year project demonstration phase.

\subsection{Test Plans}

The operation of the Blast Furnace Granulated Coal Injection System was reported in monthly and quarterly blast furnace operating reports. In addition, any special blast furnace operating parameters that were adjusted to accommodate coal injection were discussed in the quarterly operating reports submitted to the DOE and reiterated in the annual reports to DOE. Table 2 lists the topics and reference reports on the operational experiences with the BFGCI. The environmental performance of the facility with appropriate data was reported in quarterly reports beginning in 1996. Table 3 shows a listing of the quarterly environmental reports that were submitted.

A meaningful analysis of blast furnace process changes that occur with a change of injected coal type or sizing requires a base period from which comparisons can be made. The requirements for an acceptable blast furnace trial are:

1. A steady state operation of the blast furnace with a minimum of day-to-day variability. The length of the test period is flexible, however, the longer the trial duration, the more definitive the results.

2. A base period that is reasonably close, chronologically, to the trial period.

3. A minimum of major furnace process changes during the trial, particularly with the process variable that is being evaluated.

\subsubsection{Blast Furnace Trials}

There were four full blast furnace trials conducted with the BFGCI. Each trial was designed and planned to address a project goal. Table 4 lists the four trials conducted and reported on, the trial dates and the parameters that were demonstrated with the trial. 


\subsection{Operating Procedures}

The coal injection facility is comprised of many elements. Each element is controlled by process computers programmed for safe and reliable operation. In addition, the operation of the injection facility is very much influenced by the operation of the blast furnace. The process automation described below for the BFGCI is closely aligned with the systems in place for the blast furnaces.

\subsubsection{BFGCI Instrumentation and Data Acquisition}

The control system for the Blast Furnace Granulated Coal Injection System is designed to provide a steady, accurate and reliable supply of coal to the blast fumaces. The system will permit: 1) raw coal supply (car dumper to coal pile) to be controlled from the existing material handling system control station in the J-5 Junction House, 2) raw coal reclaim and coal preparation to be controlled from the control room in the Utility Building, and 3) coal injection rate to be controlled by the blast furnace operator in the existing $\mathrm{C}$ and $\mathrm{D}$ furnace control rooms.

The automation is accomplished through the appropriate use of Level 0 devices (instruments, transmitters, switches, etc.) that provide input and output for PLC's (programmable logic controllers), Level 1 devices to control equipment functions, and Level 1.5 devices-MMI's (man machine interfaces) to provide operator access to the control system.

All Level 0, Level 1 and Level 1.5 devices are interconnected through the use of hard wires, data highways and fiber optics to provide an integrated control system. The control system for coal supply, coal reclaim, coal preparation and coal injection is linked to the Blast Furnace Level 2 control system to provide data for operation of the blast furnaces and for data retrieval and archival purposes.

\subsubsection{Blast Furnace Level II Process Control}

The coal handling, coal preparation and coal injection Level 1 programmable logic controller (PLC) transfer data to the blast furnace Level II process control system. The Level 2 system performs calculations regarding the operation and performance of the furnace based on the amount of injected coal. The Level II system is also used to perform trending of the various functional data gathered by all the Level I PLC's. The Level II system sends data to the Bethlehem Steel Level III Regional Data Center for archiving.

\subsubsection{Critical Component Failure Analysis}

The equipment used for this demonstration is commercially available and has been used reliably on smaller furnaces at British Steel. There were no instances of critical component failures during the operating period at Burns Harbor beginning in 1.995 to the present. 


\subsection{TECHNICAL PERFORMANCE}

The project goals were satisfied with the four primary trials that were completed on the blast furnaces with the BFGCI system. The trials and the attributes demonstrated are shown in Table 4 and are discussed in detail below. In addition to this discussion, a complete report with detailed information was published for each of the trials as listed in Table 4.

\subsection{Blast Furnace Granular Coal Injection - Results With Low Volatile Coal}

\subsubsection{Background}

The granulated coal injection facility at the Burns Harbor Plant began operation in January 1995. Coal injection began on D furnace in mid-December 1994, primarily to test the coal grinding and preparation circuits. Significant operations began January 19 , 1995 when coal was injected through four tuyeres at a total rate of 20 pounds/NTHM. Coal injection was initiated on C furnace on February 9, 1995 using four tuyeres at an overall rate of 25 pounds/NTHM. The remaining 24 tuyeres used natural gas injection at the same time. These conditions were maintained throughout February and March. Operating difficulties with the coal grinding and preparation system, typical of new facility startup problems, required equipment changes and modifications. The first complete month of operation with coal as the sole injectant on C furnace was June 1995. On D furnace, complete coal injection began in April 1995. Since that time an operational learning curve and the development of efficient operating practices with the granulated coal facility were completed.

Sydney coal, a high volatile coal, was used on both furnaces for eight months. Six different low volatile coal types were subsequently used on both furnaces for seven months. The good operational experience with the low volatile coal resulted in a decision to use low volatile Virginia Pocahontas coal as the standard for granulated coal injection at Burns Harbor.

\subsubsection{Blast Furnace Operations}

The Burns Harbor C furnace operation during October 1996 meets the requirements for an acceptable comparative base period. The operating results for this period were used as the basis for the evaluation of future trials.

The October operation on $\mathrm{C}$ furnace was satisfactory in terms of furnace performance parameters using coal injection. The injection facility supplied coal without interruption for the entire month. The average rate of 264 pounds/NTHM varied from 246-278 pounds/NTHM on a daily basis. The furnace coke rate during the period averaged 661 pounds/NTHM. 


\subsubsection{Furnace Operating Conditions}

The $\mathrm{C}$ furnace was designated as the granulated coal test facility due, in large part, to the physical improvements made to the furnace during the 1994 reline. The $\mathrm{C}$ furnace was enlarged slightly and the refractory cooling system was upgraded to a high density plate cooling configuration. The furnace stack region on $\mathrm{C}$ has closely spaced cooling plates that are not on the $\mathrm{D}$ furnace. The high density cooling was specifically designed for the rigors of high coal injection rates and to provide for increased production capability.

The essential operating characteristics for the base test during October 1996 are shown in Table 5. These values comprise the operating base results necessary for comparison to other trials.

The type of coal used and the size distribution for the trial is of primary consideration for this period. The monthly average chemistry for the Virginia Pocahontas injection coal is shown on Table 6 . This coal is a low volatile type with high carbon and relatively low ash content. These two characteristics should provide the highest coke replacement value for the furnace process. The sulfur content of this coal is $0.78 \%$ and is considered to be mid-range. Candidate coals that were evaluated for use ranged in sulfur content from $0.32 \%$ to $1.75 \%$. The sulfur content and the impact on the furnace process are discussed in more detail later. The sizing of the final granulated coal product is also important to the blast furnace operators. Daily samples are taken on each furnace to determine the size distribution of the coal sent to the furnace. Table 6 shows the average size distribution of the coal injected on $\mathrm{C}$ furnace for October. Granular coal size for injection purposes is defined as $100 \%$ of the product coal passing a 4 mesh $(5 \mathrm{~mm})$ screen, $98 \%-7$ mesh ( $3 \mathrm{~mm}$ ) and $10-30 \%$ as -200 mesh. In contrast, pulverized coal is defined as $70 \%$ $80 \%$ of the product coal -200 mesh. The granular coal on $C$ furnace for October was $14.6 \%-200$ mesh.

The injected coal rate of 264 pounds/NTHM on C furnace during October is one of the highest achieved since the startup of the coal facility. The reliability of the coal system enabled the operators to reduce furnace coke to a low rate of 661 pounds/NTHM. The low coke rate is not only good economically, it is an indicator of the efficiency of the furnace operation with regard to displacing coke with injected coal.

Hot metal chemistry, particularly silicon and sulfur content, is another important ironmaking parameter. The end user of the molten iron, the Steelmaking Department, specifies the silicon and sulfur levels that are acceptable for their process. Low variability around the average value is necessary to achieve these specifications. The standard deviations of the silicon and sulfur content of the hot metal for October are shown in Table 5 and indicate good process control.

Table 5 also shows a typical period of natural gas injection on the $\mathrm{C}$ furnace during January 1995. Comparatively, significant operating changes occurred with the use of injected coal versus natural gas. The wind volume on the furnace decreased significantly with the use of coal. Oxygen enrichment also increased from $24.4 \%$ to $27.3 \%$ with coal. 
The amount of moisture added to the furnace in the form of steam increased most significantly from 3.7 grains/scf of blast to 19.8 grains/scf. All of these operating variables were changed by the furnace operating personnel to maintain adequate burden material movement. These actions also increased the permeability of the furnace burden column. Permeability is discussed in more detail later.

Also of significance in Table 5 is the adjustment made to the furnace slag chemistry to accommodate the increased sulfur load from the injected coal. The sulfur content of the slag increased from $0.85 \%$ with gas to $1.39 \%$ with coal. The slag volume was increased in order to help with the additional sulfur input.

Blast furnace slag chemistry and volume are determining factors in the final sulfur content in the hot metal. The blast furnace slag must be of such chemistry that it can carry the sulfur in the raw materials, including the sulfur contributed by the injected coal. Table 7 shows the sulfur balance on $C$ furnace during the month of October. Injected coal is the second largest contributor of sulfur to the blast furnace process. The blast furnace slag is the largest output for the sulfur.

The blast furnace also produces large quantities of gas. The gas exits the top of the furnace, is cleaned and some is used as a fuel in the hot blast stoves. The excess gas is consumed at the plant's boiler house. Special testing during October by the Burns Harbor Plant Environmental Department for the presence of sulfur in the gas showed an average of 3.1 grains per $100 \mathrm{scf}$ during the month. The amount of sulfur present in the gas and the total gas production is shown on Table 7. The total furnace sulfur balance shows reconciliation of the furnace sulfur input to output at $99.2 \%$.

A measure of furnace stack conditions as well as the overall furnace operation is typically known as permeability. Permeability is a function of the blast rate and the pressure drop through the furnace. A general representation of the equation used for this purpose is:

Permeability $=(\text { Furnace Wind Rate })^{2} /\left[(\text { Furnace Blast Pressure })^{2}\right.$-(Furnace Top Pressure $)^{2}$ ]

The actual calculation requires the use of several constants for atmospheric condition adjustment and the value arrived at is a pure number without units. It is used primarily for operational comparative analysis. The larger the permeability value the better the furnace burden movement and the better the reducing gas flows through the furnace column. Figure 6 is a plot of the monthly permeability and the injected coal rates from January through October 1996 . The permeability decreased from January to February as the injected coal rate was increased. Then the value increased monthly and declined somewhat to a level of 1.19 for October. This indicates an acceptable overall operation on the $\mathrm{C}$ furnace during the base test period. 


\subsubsection{Furnace Thermal Conditions and Lining Wear}

The $\mathrm{C}$ furnace is equipped with a Thermal Monitor System consisting of two components: eight thermocouples embedded in the furnace refractory at each of four furnace elevations and an extensive system of thermocouples in the discharge water of the cooling system at five furnace elevations. The heat loss in the furnace is calculated for various elevations in the furnace from the water system thermocouples.

In addition to the array of thermocouples, wear monitors have been placed in the refractories of the furnace at various elevations and quadrants. These monitors give an indication of the amount of refractory lining that is left in the furnace at the various elevations.

The increased amount of injected coal does not seem to have caused an increase in the temperatures over the first ten months of 1996. The refractory temperatures for October decreased at several elevations from some high values during January and February.

The refractory wear monitor readings from the beginning of the $\mathrm{C}$ furnace campaign indicated that brick wear increased as coal injection rates increased. However, it is not clear that this increased wear was due to coal injection. The refractory wear patterns of previous furnace campaigns at the Burns Harbor Plant show that after twenty months of service with coal injection, there is less refractory wear on $C$ furnace than during the three previous furnace campaigns without coal injection. However, the previous campaigns did not have the high density cooling configuration that was installed on the $\mathrm{C}$ furnace for the current campaign.

\subsubsection{Discussion}

A major conclusion of the use of granular coal injection for the October base test as well as the general furnace operational characteristics shown throughout 1996 is that granular coal performs very well in large blast furnaces.

The quantity of furnace coke that is replaced by an injected fuel is an important aspect of the overall value of the injectant on the blast furnace process. The replacement ratio is also a very strong indication of the quality of the overall operation with coal as the injectant. A detailed analysis of the furnace coke/granulated coal replacement value for the $\mathrm{C}$ and $\mathrm{D}$ furnaces at the Burns Harbor Plant was conducted.

The replacement ratio for a blast furnace injected fuel is defined as the amount of furnace coke that is replaced by one pound of the injectant. However, there are many furnace operating factors, in addition to the injectant, that affect the coke rate. In order to calculate a true replacement ratio for the injected coal, all other blast furnace operating variables that result in coke rate changes must be accounted for. After accounting for coke changes caused by variables other than the coal, the remaining coke difference is attributed to the injected coal. 
To develop the replacement ratio, this evaluation compares monthly average furnace operating results with an appropriate base period. Twenty-five months of data on both furnaces which includes operating results through the second quarter of 1996 were used for the regression analysis.

The adjusted furnace coke rate and the injected coal are plotted in Figure 7 along with the best fit regression line. The slope of the best fit line shows that the coal/coke replacement is 0.96 . The $C$ furnace value for October 1996 is shown separately. This value correlates well with the overall regression. This is an excellent replacement ratio and is significantly better than the $0.8-0.9$ replacement reported by other injection operations.

A second conclusion from this work is that the process can adequately handle the increased sulfur loading from the injected coal. As shown in the sulfur balances, the blast furnace slag can be adjusted to accommodate the increased sulfur input.

Thirdly, the unexpectedly large decrease in furnace permeability as a result of the use of injected coal can be partially overcome by increasing the oxygen enrichment and raising the moisture additions to the furnace.

\subsection{Blast Furnace Granular Coal Injection - Results with Higher Ash Coal}

\subsubsection{Blast Furnace Operations}

Immediately prior to the high ash trial period the operation was characterized by high production levels and a steady state for the major operating variables. During 1997, the operation was run to achieve maximum furnace production rates. This is unlike most of 1996 when the primary focus was to maximize coal injection levels and achieve low furnace coke rates.

The higher ash coal trial began on May 28, 1997 and concluded June 23, 1997. The trial period was compared to two previous operating periods: a pre-trial period from May 1 May 27, 1997, and the October 1996 base period.

\subsubsection{Trial Coal Selection}

During the entire year of 1996 , the injection coal used on both furnaces was the low volatile, high carbon content Buchanan/Virginia Pocahontas. The coal is designated by two names based on two different mine sites and the point of shipment to the plant. However, both coals are from the same seam and are very similar chemically.

The typical analysis of Virginia Pocahontas in October 1996 and the Buchanan coal used on the furnaces immediately prior to the trial period is shown in Table 8. For a trial that would assess ash content only, it was important to use a coal that varies only in ash so that there would be no confounding issues such as sulfur content or large differences in

volatile matter. To achieve this the coal supplier of the Buchanan coal suggested that ash content could be increased at the mine site cleaning plant if one of the usual coal cleaning 
steps was eliminated. Trials were run at the mine and subsequent coal analysis confirmed that the ash content could be increased with this method. The average analysis of the four train trial coal is also shown on Table 8 . The trial coal is $2.4 \%$ higher in ash than the coal used for the October 1996 base and is 3.0\% higher in ash than the coal used during the furnace period immediately prior to the trial. As demonstrated on Table 8, the three operating periods use coal that is significantly different only in ash content. Also shown in Table 8 is the size distribution of the final injection product coal for the trial period.

\subsubsection{Furnace Operations}

Table 9 shows the operating results for the high ash trial period on $C$ furnace and the two operating periods that are used to make the comparative analysis. Each of these periods is operationally similar, the amount of injected coal used during each period is about the same; the general blast conditions during the periods are comparable; the wind rates only vary from 135,370 SCFM to 137,000 SCFM; the blast pressure, top pressure and moisture additions are comparable.

\subsubsection{General Trial Observations}

There were several operating variables that were of concern and were closely monitored during the trial. Several of these parameters could have adversely affected furnace performance with the use of the high ash coal. However, the trial period confirmed that high coal ash, at the injection rate used, did not hinder furnace performance. This finding is based on data in Table 9 that shows the following:

1. Furnace permeability was not changed and the higher ash loading in the raceway did not have a deleterious effect.

2. Furnace blast pressure and wind volume were maintained at the base conditions during the trial.

3. Furnace production rates were up as delay periods declined during the trial.

4. Hot metal silicon and sulfur content and variability were comparable during all three periods

The primary change in the operation, as expected, was the increase in the blast furnace slag volume. The 461 pounds/NTHM slag volume during the trial is significantly higher than the 448 pounds/NTHM slag volume during the May 1 - May 27, 1997 period and the 424 pounds/NTHM during the October 1996 period. The general conclusion is that higher ash content in the injected coal can be adjusted for by the furnace operators and does not adversely affect overall furnace operations. 


\subsubsection{Furnace Coke Rate Results}

The primary reason for this coal trial was to determine the coke rate penalty to the blast furnace that results from the use of higher ash coal. In order to assess the comparative furnace coke rate during a trial, all the blast furnace variables that the coke rate that are different from the base must be adjusted by using coke correction factors. The only variables that are not corrected or adjusted are those affecteded by the operating variable that is being assessed. After all of the coke differences between the base period and the trial period are accounted for, the remaining coke is attributed to the variable being studied. Since the higher ash coal causes an increase in the furnace slag volume and contributes to higher furnace coke usage, the coke was not adjusted for changes in the slag volume.

Two comparisons, using the above logic, were made to validate and substantiate the results of this trial. The higher ash trial results were compared to the period immediately prior to the trial and the previously presented base period results from October 1996.

The results of the first comparison are shown in Table 10 where the high ash trial data has been corrected to the May 1 - May 27, 1997 base period. The largest coke rate adjustment necessary is for the difference in the injected coal amount of seven pounds of coke. The conclusion is that a three per cent increase in injected coal ash results in a nine pound per NTHM increase in the furnace coke rate. This is the amount of coke carbon needed to replace the carbon from the high ash coal without penalty.

The values from the second comparative period are shown in Table 11. As with the previous analysis; only small adjustments are required to establish the overall corrected coke rate. This comparison substantiates the first results. The 2.4 per cent increase in coal ash from the October 1996 base period to the trial period results in a coke penalty of eight pounds per NTHM.

The blast furnace sulfur balance for the trial period is shown in Table 12. There is good closure for the sulfur input and output.

\subsubsection{Furnace Thermal Conditions}

The refractory temperatures at several elevations did not change significantly during this time. Several elevations decreased slightly from higher values measured during February and March 1997.

The thermal load values, expressed as the heat loss of the furnace in $\mathrm{Btu} / \mathrm{hr} / \mathrm{ft}^{2}$, were practically unchanged during the trial as compared to the three previous months of normal operation with the standard ash injected coal. 


\subsubsection{Conclusions}

This coal trial demonstrated some important blast furnace operating considerations when using a high ash coal:

- There is a coke rate disadvantage of three pounds per NTHM for each one per cent increase of ash in the injection coal at an injection rate of 260 pounds per NTHM.

- Higher ash coal had no adverse affect on the furnace permeability.

- The productivity of the furnace was unaffected by the three percent increase in coal ash at the injection rate of 260 pounds per NTHM.

- Hot metal quality was unaffected by the increased ash content of the injection coal.

\subsection{Blast Furnace Granular Coal Injection Results Using Pulverized and Granulated High Volatile Coal}

This section presents the results of two trials conducted using granulated and pulverized high volatile coal from Colorado. The first trial was conducted to quantify the effect that a high volatile western coal, Colorado Oxbow, has on the blast furnace operation and the process economics compared to the eastern low volatile coal that is the current standard at Burns Harbor. The high volatile western coal was pulverized for the second trial. The pulverized trial period was compared to the granular period using the high volatile coal and analyzed for blast furnace process differences.

The first trial, the comparison of high to low volatile coal, is an important aspect of the demonstration project. This trial shows the role that coal chemistry, specifically carbon and ash content, has on the blast furnace process. The objective of the second trial was to determine if injected coal size, i.e., pulverized versus granulated, has an impact on blast furnace performance. This comparison of pulverized versus granulated coal was an important part of the demonstration project.

Table 13 shows the operating periods used on $\mathrm{D}$ furnace for the two trials. Operating data from August 1998 were used as the base period to compare the furnace operation using low volatile granular coal with the trial of granular high volatile coal conducted in October 1998. The second trial was with pulverized Colorado coal. These trial results were compared to those of the granulated Colorado coal trial. This trial was planned to run the full month of November; however, extreme wear to the grinding mills during the granular trial resulted in the inability of the mill to pulverize the coal. Consequently, the first two weeks of November were used for emergency repairs. The pulverized coal trial began on November 13 and concluded on November 26 when the Colorado coal supply was depleted. 


\subsubsection{The D Furnace Operation}

The planning for these trials and the procurement of the high volatile coal from Colorado began during the spring of 1998 . Five trainloads, approximately 40,000 tons, of the coal was ordered for delivery beginning in September. The trial period was to begin on C furnace on October 1, 1998. However, operating difficulties, unrelated to coal injection, began to plague $\mathrm{C}$ furnace. Several major outages on $\mathrm{C}$ furnace during late September and extending throughout the trial period in October resulted in poor operating conditions. It was also necessary to switch $\mathrm{C}$ furnace to natural gas from coal injection in order to stabilize the furnace operation. The frequent delays and the use of natural gas resulted in a lack of meaningful data with coal injection. Since the Colorado coal supply was dwindling and the prospects of $C$ furnace returning to a suitable operating standard was unlikely, the trial was switched to $\mathrm{D}$ furnace. The first two comparison periods on $\mathrm{D}$ furnace, complete monthly periods during August and October, proceeded as planned. However, the pulverized, high volatile period which was also planned as a full month trial during November had to be shortened. On November 1, when the coal-grinding mill was adjusted to produce pulverized coal, the resulting coal did not meet the sizing requirements. A close examination of the mills revealed that the high volatile coal used during the previous month had severely worn the bull ring on both mills and pulverizing was not possible. Emergency repairs for resurfacing the bullrings of both mills began immediately. Twelve days were required to repair and reset the mills to produce pulverized coal. Fortunately, enough Colorado coal remained to conduct a fourteen-day trial before the supply ran out on November 27.

\subsubsection{General Trial Observations}

The use of granular low volatile coal.at Burns Harbor began during 1996 and resulted in excellent operating performance. These operating results and a subsequent DOE trial conducted in October, 1996 established a good benchmark on the use of granular low volatile coal for injection in the blast furnace. The base operating period selected for this trial, August 1998, reflects the advantages of the granular low volatile coal and is shown in Table 13. The coke rate of 683 pounds/NTHM at a coal injection rate of 250 pounds/NTHM resulted in an overall low fuel rate of 935 pounds/NTHM and contributed to the good production level of $7078 \mathrm{NTHM} /$ day.

The blast furnace operation using granular, high volatile, western coal during October is shown on Table 13. Compared to the base period, the coke rate is 115 pounds higher at 798 pounds/NTHM. Although the injected coal rate is about 60 pounds/NTHM lower at 190 pounds/NTHM, the increase in coke rate is not proportional to the injected coal decrease. This comparison shows that the low volatile coal supports a lower furnace coke rate than the high volatile coal.

The results of the blast furnace performance with pulverized high volatile coal are shown as Trial 2 in Table 13. The coke rate, coal injection rate and the overall fuel rate are very similar to the operation using granular high volatile coal. The injected coal rate is lower during this period because the two coal grinding mills could only pulverize 183 
pounds/NTHM of coal. The comparison of the two trial periods shows similar results and leads to the conclusion that the blast furnace process is unaffected by the injected coal being granulated or pulverized.

\subsubsection{Coal Chemistry and Sizing}

The comparison of injected coal chemistry between the Buchanan and the high volatile, Oxbow coal is shown on Table 14. The large difference in coke rate seen between the aforementioned periods is attributable to the difference in carbon content of the two coals. The Oxbow coal averages $73.2 \%$ carbon versus $86.3 \%$ for the Buchanan low volatile coal. The increase in coke rate is also due to the higher ash content of the Oxbow coal. Buchanan ash content is $5.23 \%$ compared to $11.20 \%$ for the Oxbow. The furnace slag volume during the operating period with Buchanan is 430 pounds/NTHM. The higher ash content of the Oxbow causes the slag volume to rise to 461 pounds/NTHM during the first trial. A slag volume increase in the blast furnace results in an increase in the coke rate.

Coal sizing was a concern and was closely monitored during each trial period. Table 15 shows the injected coal sizing for each period as well as the raw coal sizing. The raw coal sizing shown is the size fraction of the coal as measured-by the supplier at the shipping site. The product coal sizing shown in the table is the size fraction of the injection coal after grinding in the preparation mills. The granular sizing shown for the low volatile, Buchanan and the high volatile, Oxbow coal is the monthly average of daily samples taken on D furnace during August and October. The values for the pulverized sizing are the average of ten daily samples taken during the pulverized trial. The pulverized coal only shows the minus 200 mesh fraction because, unlike the granular size, the pulverized coal particles stick together and the measurement is made using a device with only one screen. This equipment puts the entire sample under vacuum and draws the portion of coal that is -200 mesh through the screen. This method of analysis was done on a daily basis to insure that the grinding mills were set properly. A more accurate method of screen analysis, the wet screen method, is often used. The Burns Harbor Plant laboratory is not equipped for this method; however, two samples were sent to an independent laboratory for wet analysis. The average of the two samples is also shown on Table 15. This method shows that the minus 200 -mesh fraction of the injected coal is $74 \%$.

The raw coal sizing shown on Table 15 demonstrates a fundamental difference between high volatile and low volatile coal. The low volatile coal arrives at the coal grinding facility with $83 \%$ of the coal already sized at minus one-quarter inch. The grinding mills require less energy to achieve the proper sizing for injection than for the high volatile coal that is only $36 \%$ minus one-quarter inch. In addition, grinding the low volatile coal with an HGI of 100 is much easier than grinding the Oxbow coal that has an HGI of $46-$ 48. 


\subsubsection{Furnace Coke Rate Results}

The result of the first comparison of the base period to the granulated high volatile period is shown in Table 16. The primary correction for the October period is the rather large difference in the injected coal rate. A correction of one pound of injected coal replacing one pound of coke is used for the difference in injection rate. Hot metal silicon content did increase substantially during the granular trial period and a correction of 11 pounds is used for this factor. After each factor in the analysis is accounted for, we are left with a 46 pound/NTHM higher coke rate in the high volatile trial period than during the low volatile base period. The higher coke rate is attributed to the use of the high volatile coal. This result is plausible because the Buchanan coal is $13 \%$ higher in carbon content than the Oxbow coal. Since carbon is the primary fuel and reductant for the furnace, the difference in fuel rates is understandable. In addition, the almost $6 \%$ higher ash content of the western coal is a distinct coke disadvantage. The previously mentioned higher ash coal trial documents a coke disadvantage of three pounds per NTHM for each one percent increase in the ash content of the injected coal. Regardless of where and how each furnace factor is applied, the overwhelming conclusion from this comparison is that the low volatile coal provides a very substantial coke rate advantage to the blast furnace.

The coke comparison of the high volatile granular trial to the pulverized trial is shown in Table 17. The operating periods are very similar and there were only small corrections necessary. We included blast furnace slag volume in these corrections because the injection coal type was the same for both periods. The largest corrections were for the decrease in wind volume during the pulverized period and the increase in slag volume. The wind decreased because the furnace permeability was lower. The three pound coke difference for the pulverized trial period is within the plus or minus five-pound error limit and strongly indicates that there is no difference in the blast furnace operation with the use of pulverized coal.

Table 18 shows the blast furnace sulfur balance results for both of the trials. The sulfur content of all of the raw material inputs, as well as the material outputs, uses the monthly average analysis. The sulfur content of the blast furnace gas is the average of three samples that were taken for each period by Mostardi Platt. The balances are very good for both trial periods.

\subsubsection{Coal Grinding Energy Consumption}

A significant consideration in adopting the British Steel granular coal injection technology was the reduced grinding cost compared to pulverized coal. This is illustrated in Figure 8 showing the combined energy consumption of both coal grinding mills per ton of coal processed. Four points of interest are shown on the figure.

The first point, May 1998, is a period during which we attempted to pulverize low volatile coal. During this month, pulverized coal was produced in the mill but severe line plugging did not allow for an appropriate furnace process trial. This experience was detailed in the quarterly status report for the period April-June 1998. The energy 